\title{
Esvaziamento e transformação morfológica da área central de Santos/SP: gênese e perspectivas
}

\author{
Emptying and morphological transformation of the central area of Santos/SP: \\ genesis and perspectives
}

Marina Ferrari de Barros[a,b] (D), José Marques Carriço[a,c] (D)

\author{
[a] Prefeitura Municipal de Santos, SP, Brasil \\ [b] Universidade Santa Cecília (UNISANTA), Santos, SP, Brasil \\ [c] Programa de Pós-graduação Stricto Sensu em Direito Ambiental e Internacional, Universidade Católica de \\ Santos (UNISANTOS), Santos, SP, Brasil
}

Como citar: Barros, M. F., \& Carriço, J. M. (2019). Esvaziamento e transformação morfológica da área central de Santos/SP: gênese e perspectivas. urbe. Revista Brasileira de Gestão Urbana, 11, e20180100. https://doi.org/10.1590/2175-3369.011.e20180100

\section{Resumo}

A partir da análise de uso do solo e do processo de urbanização de Santos, verificou-se que sua área central apresentou, no século XX, expressivo processo de esvaziamento, sobretudo habitacional, refletindo em atividades econômicas vinculadas ao consumo das famílias. Esse processo foi motivado pelas transformações econômicas, que afetaram o papel dessa área, ao mesmo tempo que o crescimento do porto e a ampliação dos impactos de suas atividades de apoio, legitimadas pelos zoneamentos em vigor durante o período, promovendo mudanças morfológicas deletérias. Esse fenômeno foi acompanhado pela evasão de famílias com maior rendimento, permanecendo na área famílias de baixa renda, que ocuparam antigos casarões convertidos em cortiços, em extrema precariedade. A partir dos anos 1990, desenvolveu-se uma política de preservação do patrimônio histórico dessa área, contribuindo para manter algum dinamismo econômico, sem, contudo, articular-se à ineficaz política habitacional, adotada em 2010. No entanto, disseminou-se um falso entendimento de que a promotora do esvaziamento foi a política de proteção. Porém, verifica-se que, se aperfeiçoada, essa política poderá promover o repovoamento da área, com adequado direcionamento de investimentos, orientados por novo regramento urbanístico, que garanta respeito à sua paisagem natural e edificada, bem como priorize famílias de baixa renda.

Palavras-chave: Área central. Morfologia urbana. Repovoamento. Patrimônio histórico. Santos.

\section{Abstract}

From the analysis of land use and the urbanization process of Santos, during the $20^{\text {th }}$ century, its central area presented an expressive process of emptying, especially housing, reflecting economic activities related to household consumption. This process was motivated by the economic changes that affected the role of this area, concomitantly to the growth of the port and the amplification of the impacts of its support activities, legitimized by the zoning in force during the period, promoting deleterious 
morphological changes. This phenomenon was accompanied by evasion of families with higher income, remaining low-income families in the area, who occupied old mansions converted into tenement homes, in extreme precariousness. From the 1990s, a policy was developed to preserve the historical heritage of this area, contributing to maintaining some economic dynamism, without however being articulated with the ineffective housing policy adopted in 2010. However, a false understanding was spread that the policy of protection was the promoter of emptying. Nevertheless, it can be verified that, if perfected, this policy may promote the repopulation of the area, with appropriate targeting investments, guided by a new urban regulation, which guarantees respect for its natural and built landscape, prioritizing lowincome families.

Keywords: Central area. Urban morphology. Repopulation. Historical heritage. Santos.

\section{Introdução}

A "naturalização" de processos de transformação de áreas urbanas, atribuindo a agentes anônimos seus resultados, bem como suas formas a tendências inexoráveis, além do conteúdo ideológico evidente, incorpora à política urbana uma função exclusiva de gerenciamento, restringindo seu papel enquanto instrumento democrático de atuação sobre a cidade.

Se "política" é ação em sociedade, então o significado de política urbana está ligado à atuação do planejamento urbano enquanto instrumento influenciador das relações sociais que têm como substrato o espaço urbano. Assim, a exposição honesta dos processos de transformação e seus agentes, a partir de diagnóstico aprofundado da realidade urbana, é prática desejável para a reformulação dessa política.

Dessa forma, a análise morfológica traz grande contribuição ao associar forma urbana aos fenômenos sociais que a geraram, corrigindo distorções e filtrando a ideologia por trás dos discursos explicativos difundidos na sociedade. Portanto, este trabalho recupera a análise do uso do solo como ferramenta para revisão da política urbana voltada à regulação da produção, à gestão do espaço urbano e à proteção cultural, no município de Santos/SP1.

O estudo ora apresentado compreende a Região Central Histórica ${ }^{2}$ dessa cidade, na qual predomina a política de proteção cultural do município em uma área já bastante esvaziada de suas principais funções urbanas, especialmente habitação.

Para tanto, foram elencados levantamentos morfológicos que traduzem o impacto do planejamento urbano, influenciados pela legislação urbanística quanto ao desenho urbano e ao uso da área. A análise comparativa do uso do solo utilizou levantamentos de 1985 e 1986, comparados, posteriormente, com o de 2014. 0 ano de 2002 também foi abordado na comparação, no que se refere a imóveis vazios e desocupados, tornando mais tangível a percepção da política de proteção cultural implementada.

A análise histórica da regulamentação do uso e da ocupação incidente na área constitui importante variável, pois, como elemento regulador, tem impacto na construção do ambiente urbano e reflete fenômenos sociais, os quais, em conjunto com fatores contextuais e de ordem econômica, geraram formas hoje encontradas.

Assim, resgatou-se a evolução do zoneamento incidente na área central, de 1922 a 2014, lembrando que a modificação da distribuição das atividades na área se relaciona com efeitos espaciais de diferentes estágios econômicos, os quais repercutem nas políticas de planejamento da ocupação, por meio de leis urbanísticas, atendendo a concepções sociais da cultura dominante a respeito da imagem do grupo social, a ser especializada por símbolos, no território concreto da cidade. A partir dessa análise, clarificou-se o papel da regulação urbanística como elemento de reforço ao processo de esvaziamento evidenciado pelas alterações morfológicas.

\footnotetext{
${ }^{1}$ Santos, polo da Região Metropolitana da Baixada Santista e sede do maior porto da América do Sul, ocupa parcialmente a Ilha de São Vicente, mas sua maior parte se estende pelo continente. É na área insular que vivem 99\% da população, de acordo com o censo demográfico do IBGE, de 2010.

${ }^{2}$ A Região Central Histórica de Santos foi delimitada pela Lei Complementar no 470, de 5 de fevereiro de 2003 (Santos, 2003 ), como área de abrangência do Programa de Revitalização e Desenvolvimento, denominado Alegra Centro, compreendendo 11 bairros.
} 
Também se relacionam com esses fatores os principais vetores de expansão urbana, que impactaram no deslocamento dos antigos moradores do Centro para novas localizações próximas à orla marítima, ao longo das avenidas, que garantiram a conexão entre ambas as áreas.

Nesse aspecto, foi decisiva a implantação do Plano de Saneamento de Santos, no início do século XX, pela Comissão de Saneamento do Estado de São Paulo, em especial o sistema de macrodrenagem, implantado na atual Zona Leste da cidade, que garantiu condições para a expansão urbana, com produção de loteamentos e atendimento, por linhas de bonde, do novo território, livre de alagamentos.

A convivência de todos os grupos sociais e de todas atividades, no mesmo local, gerou conflitos resolvidos com a criação de novos bairros residenciais, primeiramente com o Paquetá e o Vila Nova e, posteriormente, com os bairros mais distantes da orla, rompendo com qualquer lógica de racionalização do uso da terra, ao promover crescimento descontínuo da mancha urbana.

Essa situação não é específica de Santos, mas aqui foi muito prejudicial, considerando a exiguidade de território passível de utilização, em um quadro de abandono paulatino da área central com duplo efeito em termos espaciais, como será explorado a seguir, com ênfase em seus aspectos morfológicos. Se, por um lado, o Centro perdeu população continuamente, em processo que ocorre até o presente, também se esvaziando como centralidade terciária, por outro, ao abdicar do controle da ocupação do novo território viabilizado pelo Plano de Saneamento, o município passou a apresentar, na mencionada Zona Leste, tecido urbano fragmentado e, em certa medida, desconexo, cujas consequências deletérias em termos de paisagem, mobilidade e oferta de espaços livres também serão exploradas neste trabalho.

\section{A forma como método de análise}

Conforme Del Rio (1990, p. 67), existem várias teorias e propostas metodológicas para o desenho urbano, porém "nenhuma delas é completa e suficiente por si própria e todas vêm complementar as metodologias de Planejamento Urbano e Arquitetura já conhecidas, que continuam necessárias para a análise e o Desenho Urbano". Apoiado em Lang (1987, p. 14)³, Del Rio acrescenta que "teorias-bemsucedidas consistem de generalizações simples mas poderosas sobre o mundo e como ele funciona, de modo a nos permitir predizer com precisão as operações futuras". Esse autor defende que, para o desenho urbano, são necessárias diversas teorias, utilizando-se de cada uma segundo a especificidade do problema. Nesse sentido, o estudo da morfologia, derivado da geografia ${ }^{4}$, é ferramenta adequada para análise dos processos aqui descritos. Para Whitehand (apud Del Rio, 1990, p. 70), o "período morfológico" é "fase da história social e cultural que gera formas materiais distintas", questão crucial à compreensão das transformações operadas na área central de Santos, identificando-se agentes e contexto histórico.

Ainda considerando essa perspectiva de análise para Santos, Whitehand (2013) relembra como Conzen associou, na origem da conceituação dos estudos morfológicos, a relação entre método de análise da forma e planejamento urbano, indicando que o passado oferece lições para o futuro das áreas urbanas. 0 "mapa" com espacialização das características físicas e sua evolução ao longo do tempo assim podia ser "ajustado às necessidades de planeamento, fornecendo as bases para enraizar a gestão futura da paisagem urbana no seu desenvolvimento histórico".

A análise empreendida neste trabalho se enquadra mais especificamente em uma das linhas fundadas por Conzen apud Whitehand (2013), "a ligação entre os processos de tomada de decisão e a forma urbana", pois procurou-se evidenciar os indivíduos que criam as paisagens urbanas, os quais, conforme o geógrafo, raramente ocupam a "frente do palco".

Entende-se que estudos morfológicos nas administrações municipais são pouco explorados, pois raramente se constituem em métodos de trabalho. Verificam-se mesmo práticas que podem inviabilizar

\footnotetext{
${ }^{3}$ Lang busca desenvolver uma teoria da arquitetura com base nas ciências comportamentais.

${ }^{4}$ Del Rio (1990, p. 70) atribui a origem do conceito de morfologia urbana a geógrafos alemães e franceses do início do século XX, com atuação de ingleses na década de 1980, sendo na Itália a origem da aplicação dessa metodologia na arquitetura e no urbanismo, mais especificamente na preservação do patrimônio histórico.
} 
estudos futuros, com perda de registros históricos das transformações da cidade, como substituição, nas plantas cadastrais, do "antigo" pelo "novo". Plantas históricas não raro são perdidas pela má conservação, e estudos importantes realizados permanecem desconhecidos.

Embora a gênese do urbanismo no Brasil seja também caracterizada pela relação existente entre estudo e prática do planejamento urbano, conforme propõe Leme (1999), no sentido de que técnicos municipais eram os mesmos a ocupar salas de aula, ainda hoje verifica-se esse descompasso entre produção acadêmica e atuação técnica sobre a cidade, observado pela autora para o período analisado em sua obra. Acredita-se que não apenas há incompreensão daqueles que executam a política urbana, mas também vontade deliberada de ignorar dados e fatos, pois seu reconhecimento expõe, muitas vezes, a ideologia pouco inclusiva que os move.

\section{A "diáspora" santista}

O abandono de áreas centrais é processo recorrente no mundo, produzido por fatores concomitantes ou não, como valorização imobiliária, regulação urbanística, procura de melhores localizações e fuga dos impactos ambientais promovidos por atividades não residenciais. Contudo, em Santos, o processo foi tão intenso, que, para qualificá-lo, metaforicamente, pode-se utilizar a expressão "diáspora".

O esvaziamento do Centro de Santos pela população residente ocorre continuamente, desde o final do século XIX, e atingiu seu ápice na segunda metade do século passado, conforme a Tabela 1, que também revela o adensamento da Zona Leste, até 1980, evidenciando maior crescimento das áreas dos Morros e da Zona Noroeste, que passaram a ser alternativas locacionais das famílias de baixa renda. De acordo com esses dados, em 2010, a população do Centro equivalia a 10\% da registrada em 1950.

Se for considerado o recenseamento do município de 1913, a área central, acrescida do loteamento Vila Macuco, cuja área não está incluída na região Centro da tabela, pode-se contabilizar 68.631 residentes. Como o referido loteamento era recente na época, pode-se considerar que esse número de habitantes está próximo do que residia na região Centro, permitindo avaliar o esvaziamento ocorrido a partir do início da implantação do Plano de Saneamento5. Conforme esses dados, em 1950, a população residente na área equivalia, aproximadamente, a 64\% da população recenseada em 1913.

Tabela 1 - Evolução da população na área insular de Santos (1950-2010)(1)

\begin{tabular}{cccccccc}
\hline \multirow{2}{*}{ Regiōes } & \multicolumn{7}{c}{ População } \\
\cline { 2 - 8 } & 1950 & 1960 & 1970 & 1980 & 1991 & $\mathbf{2 0 0 0}$ & $\mathbf{2 0 1 0}$ \\
Centro(2) & 44.401 & 44.130 & 31.942 & 18.566 & 10.552 & 6.982 & 4.307 \\
Leste & 134.700 & 177.888 & 242.924 & 309.731 & 308.732 & 293.088 & 295.788 \\
Noroeste & 4.194 & 18.095 & 37.867 & 60.588 & 66.985 & 81.589 & 83.095 \\
Morros (3) & 11.673 & 19.185 & 27.172 & 28.822 & 29.333 & 34.088 & 33.043 \\
Total (4) & 194.968 & 259.298 & 339.905 & 417.707 & 415.602 & 415.747 & 416.233 \\
\hline
\end{tabular}

Fonte: Carriço \& Barros (2015), com base nos censos demográficos do IBGE (1950 a 2010). (1) A área insular do município de Santos, onde residem $99 \%$ de sua população (IBGE, 2010), é formada pelas áreas Centro, Leste, Noroeste e Morros, as quais possuem características morfológicas e socioespaciais específicas, sendo a Zona Leste a área que se estende entre o Centro e a orla marítima, concentrando a maior parte da população, predominantemente de média e média-baixa rendas, enquanto Morros e Zona Noroeste são áreas habitadas por população majoritariamente de baixa renda; (2) Área central inclui os bairros: Centro, Valongo, Paquetá, parte da Vila Nova e Monte Serrat; (3) Computadas áreas ocupadas e ocupáveis nos Morros, exceto em 2010, em que estas foram consideradas; (4) Total da área insular do município.

\footnotetext{
${ }^{5} \mathrm{O}$ sistema de macrodrenagem começou a ser implantado por Saturnino de Brito em 1907, e o de coleta de esgoto, em 1912.
} 
Esse processo decorreu de eventos importantes, como a inauguração, em 1867, da ferrovia São Paulo Railway Company, conhecida como Santos-Jundiaí, que permitiu o deslocamento mais rápido entre Santos e o planalto, resultando na primeira fase de ocupação da orla marítima pela elite cafeeira. A abertura das avenidas Conselheiro Nébias e Ana Costa substituiu o antigo Caminho da Barra, como ligação entre o Centro e as praias, fazendo surgir casarões de famílias abastadas nessas vias.

Também permitiu a introdução do sistema de bondes tracionados por muares, cuja primeira linha entre Centro e barra foi inaugurada em 1873. Em 1887, outra linha passou a atender a Vila Mathias, loteamento pericentral então recém-implantado. Dois anos depois, foi inaugurada a segunda linha para a Barra, conectando o Centro à área conhecida como Gonzaga, que começava a ser loteada.

O binômio bonde-loteamento promoveu a ocupação paulatina da planície entre Centro e orla, de forma fragmentada e descontínua. Não raro, empresários atuantes em um ramo atuavam em outro, como Mathias da Costa, responsável pelo primeiro serviço de bondes, pelo loteamento da Vila Mathias e pela abertura da avenida Ana Costa.

Em 1892, a Companhia Docas de Santos inaugurou o primeiro trecho de cais do Porto, em meio à grave crise sanitária, descrita detalhadamente em Andrade (1989). As epidemias veiculadas por mosquitos que infestavam as áreas alagadiças colocaram em risco a reprodução da economia cafeeira, que tinha no porto de Santos sua base principal.

$\mathrm{Na}$ última década daquele século, as obras do porto e algumas intervenções da municipalidade, no precário sistema de saneamento, contribuíram para a melhoria das condições ambientais. Em 1909, a Companhia City inaugurou o serviço de bondes elétricos. Não por acaso, essa empresa também promovia a construção de loteamentos. Esse serviço, ativo até 1971, com o Plano de Saneamento, viabilizou a ocupação da Zona Leste, à medida que os loteamentos reconfiguravam a paisagem da planície marinha.

A rede de canais de drenagem do Plano de Saneamento, concebido pelo engenheiro Saturnino de Brito, foi seu componente mais importante, o que hoje confere identidade à cidade, drenando terrenos alagadiços e criando condições para a ampliação do tecido urbano até a orla marítima (Figura 1).

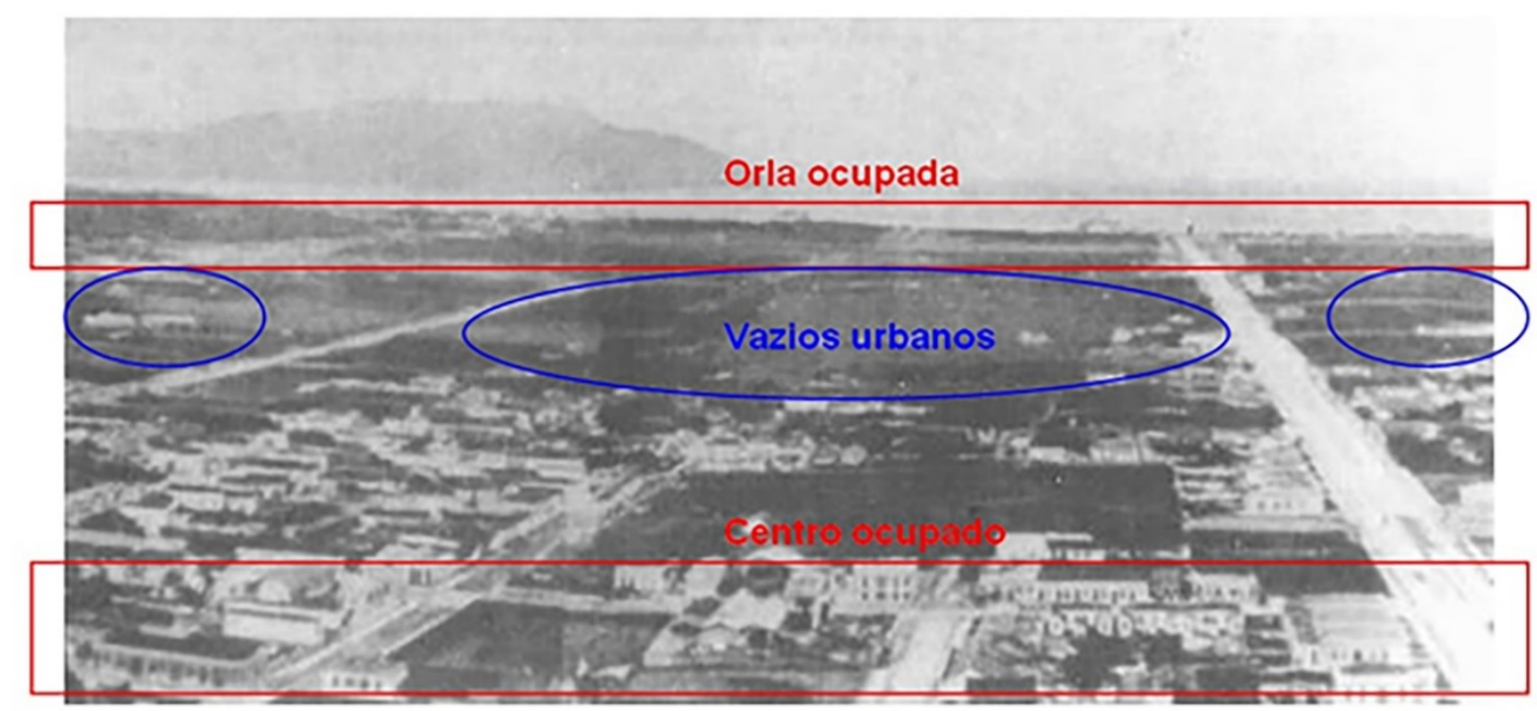

Figura 1 - Ligação entre o Centro e a orla em expansão descontínua no início século XX. Fonte: elaborada pelos autores a partir de fotografia publicada em Andrade (1995).

Se o Plano de Saneamento criou condições para o abandono da área central, um novo processo de deslocamento da população passou a ocorrer, na segunda metade do século passado, em direção aos municípios vizinhos. Conforme se observa na Tabela 2, desde os anos 1970 a população de Santos se estabilizou por causa da saturação urbana ocorrida já no decênio anterior e da consequente migração das famílias, primeiro em direção a São Vicente e Guarujá, depois em direção ao sul da região, sobretudo Praia Grande. 
A regionalização da Baixada Santista ocorreu fundamentalmente por dois processos concomitantes de migração. O primeiro, de âmbito nacional, em razão da arregimentação de mão de obra para expansão do Porto e das indústrias de Cubatão, partiu da estratégia de industrialização brasileira no período. 0 segundo, de caráter local, resultou da ampliação do custo da habitação, em Santos, à medida que se esgotavam terrenos ocupáveis na área insular, ocasionando fixação da maioria das famílias com baixa renda em assentamentos precários, em localizações periféricas da área insular, assim como de extratos inferiores da classe média nos municípios vizinhos.

Tabela 2 - Brasil, Estado de São Paulo, Região Metropolitana da Baixada Santista e Santos: evolução da população residente (1950 a 1980)

\begin{tabular}{ccccccccc}
\hline \multirow{2}{*}{ Abrangência } & \multicolumn{7}{c}{ População residente } \\
\cline { 2 - 9 } & $1950(1)$ & 1960 & 1970 & 1980 & 1991 & 1996 & $\mathbf{2 0 0 0}$ & $\mathbf{2 0 1 0}$ \\
Brasil & 51.944 .397 & 70.070 .457 & 93.139 .037 & 119.002 .706 & 146.825 .475 & 157.079 .573 & 169.799 .170 & 190.755 .799 \\
SP & 9.134 .423 & 12.809 .231 & 17.771 .948 & 25.040 .712 & 31.588 .925 & 34.120 .886 & 37.032 .403 & 41.252 .160 \\
RMBS & 267.387 & 416.963 & 653.441 & 961.249 & 1.220 .249 & 1.309 .263 & 1.476 .820 & 1.664 .136 \\
Santos & 203.582 & 262.997 & 342.055 & 412.448 & 417.450 & 412.243 & 417.983 & 419.400 \\
\hline
\end{tabular}

Fonte: Carriço \& Souza (2016), com base nos censos demográficos do IBGE (1950 a 2010). (1) População presente.

Se o deslocamento populacional do início do século XX ocorreu com a expansão do tecido urbano em direção à orla marítima, possibilitada pelo Plano de Saneamento, o processo da segunda metade do século ocorreu em condições muito piores, no tocante à infraestrutura urbana, pois a ocupação dos demais municípios da região ocorreu, com raras exceções, em um tecido mais fragmentado e desconexo, fruto da atividade imobiliária majoritariamente voltada para produção de unidades de veraneio, à custa da supressão de restingas e manguezais e com absoluta precariedade em termos de saneamento (Instituto Pólis, 2013).

Se a precariedade habitacional é recorrente nas localizações mais distantes da Zona Leste e nos Morros da área insular, na área central de Santos há boas condições para repovoamento, em virtude da disponibilidade de infraestrutura, da oferta de trabalho e da provável implantação da segunda fase do veículo leve sobre trilhos (VLT), que conectará essa área aos municípios vizinhos. Isso poderá criar oportunidade de implantação de política urbana com foco na equidade social, em parte da área suscetível à renovação urbana, assim como reabilitação de edifícios degradados, privilegiando uso misto e diversidade de faixas de renda atendidas e priorizando as que constituem a maior demanda.

Para visão detalhada dos problemas e da potencialidade dessa área em termos de adensamento, será apresentada, em seguida, análise da morfologia urbana, em especial quanto à evolução do uso e da ocupação do solo, em períodos determinados pela disponibilidade de dados no setor de planejamento urbano da Prefeitura de Santos.

\section{Estudos de morfologia urbana}

Apresentam-se a seguir resultados dos estudos de morfologia urbana do Centro de Santos, realizados em 2016 pela equipe da Coordenadoria de Planejamento Urbano (COPOLUR), da Secretaria de Desenvolvimento Urbano (SEDURB), da Prefeitura de Santos, cujo objetivo foi levantar a identidade da área para definição de parâmetros regulatórios de intervenção e ocupação compatíveis com a preservação do patrimônio cultural.

Para além dos imóveis tombados e protegidos isoladamente, a área tem importância como paisagem construída na sua inter-relação com o ambiente natural e sob valores sociais e culturais, que lhe dão 
forma e sustentação. Assim, realizou-se levantamento dos atributos físicos que conformam o suporte concreto da paisagem por meio da análise morfológica do espaço.

Definiu-se como área de abrangência (Figura 2) a mesma do programa Alegra Centro (Santos, 2003), realizando-se análise comparativa da evolução do uso do solo por meio de levantamentos de uso do solo qualificado, realizados entre 1985 e 1986, e da identificação da distribuição das atividades, predominância de usos, especialização e diversidade, em 2014. Metodologicamente, cada atividade corresponde a um lote, o qual pode abrigar mais de uma atividade.

Paralelamente, levantou-se a estrutura fundiária da área mediante a identificação e a análise da ocupação das quadras e dos lotes e sua influência na caracterização do lugar, com utilização da técnica figura/fundo.

Efetuou-se ainda levantamento do crescimento por intermédio de identificação e análise das fases de ocupação da área, modo de crescimento, direção e transformação, o que permitiu uma análise comparativa da evolução da ocupação e da distribuição das atividades.

Outros levantamentos foram realizados, mas o foco deste trabalho é a análise comparativa das transformações de uso do solo e das tipologias dos elementos urbanos, explorando a interface entre estas e a regulação urbanística, em especial quanto ao zoneamento incidente entre 1922 e 2014, visando captar repercussões no que se refere ao esvaziamento da área e à política de proteção do patrimônio histórico.

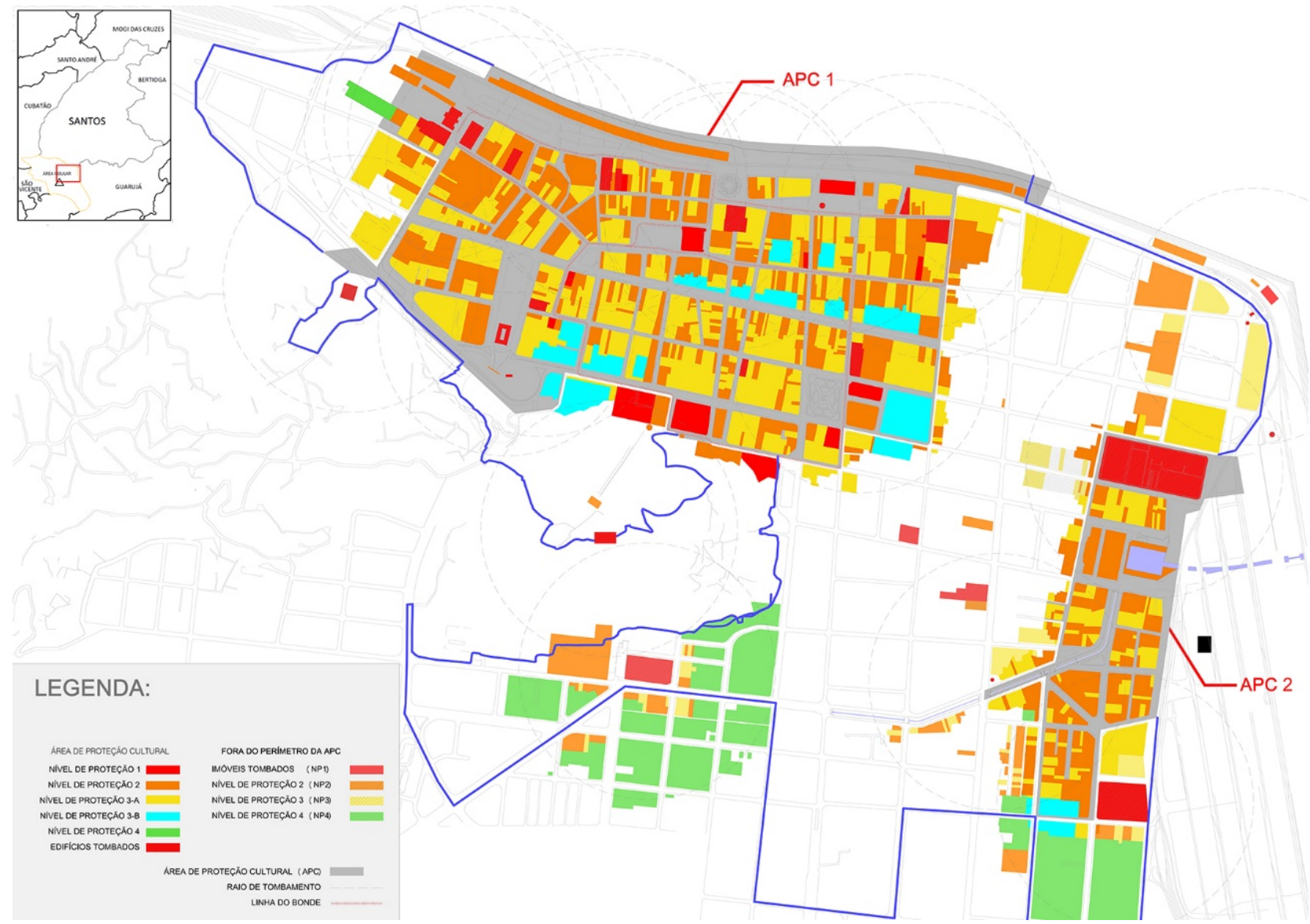

Figura 2 - Área de abrangência do estudo. Fonte: Santos (2016). 


\section{Análise comparativa das transformações de uso do solo}

Na Figura 3, apresentam-se levantamentos gerais de uso do solo qualificado, em duas épocas distintas, para permitir análise comparativa.

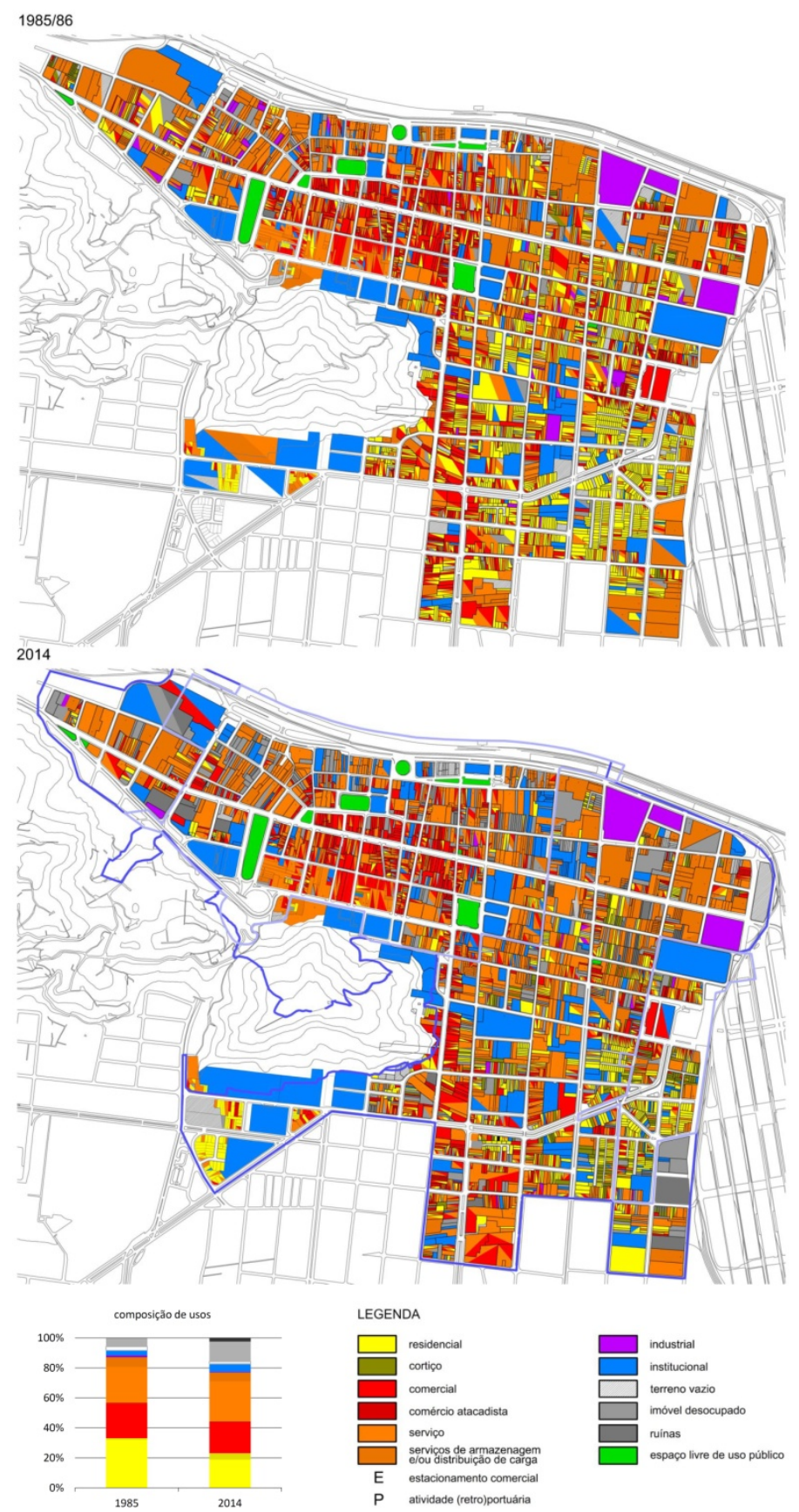

Figura 3 - Levantamentos gerais de uso do solo qualificado (1985/1986-2014). Fonte: Santos (2016).

Na Figura 4, apresenta-se, isoladamente, a evolução do uso residencial, incluindo edificações coletivas de aluguel (cortiços). Comparando-se os períodos (ver gráfico na figura), observa-se que o número de residências caiu em torno de $36 \%$ e o de cortiços teve aumento de $258 \%$, revelando expressiva ampliação da precariedade residencial na área.

Conforme estudo da evolução do zoneamento, apresentado adiante, é provável que as atividades portuárias instaladas no bairro Paquetá tenham deslocado os cortiços para a área do Mercado Municipal, situada entre os bairros Paquetá e Vila Nova. 
Verifica-se ainda que as residências praticamente desapareceram dos principais eixos viários, nos quais circula o transporte coletivo, pois, onde há mais transporte disponível, há menos residências.

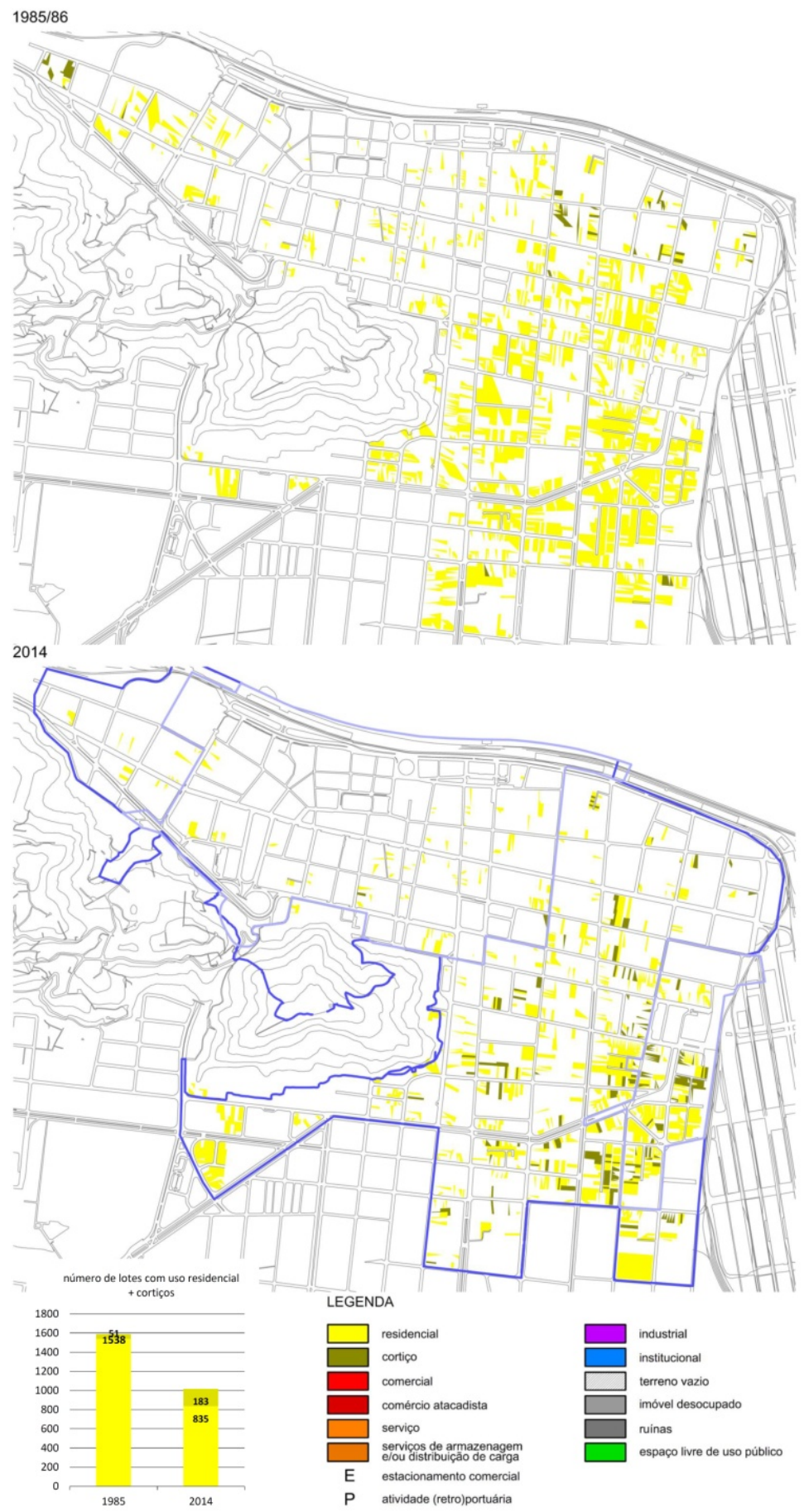

Figura 4 - Levantamentos de uso do solo residencial (1985/1986-2014). Fonte: Santos (2016).

Na Figura 5, apresenta-se a evolução do uso comercial, incluindo comércio varejista e atacadista. Comparando-se os períodos, observa-se que o comércio varejista diminuiu $26,5 \%$, e o atacadista, $35 \%$. Portanto, há generalizada perda de dinamismo econômico na área, sobretudo nos bairros Paquetá e Vila Nova.

Essa dinâmica indica que o comércio foi fortemente afetado pelo esvaziamento residencial em toda a área, e, sobretudo, atividades vinculadas ao consumo das famílias podem ter desaparecido ou se deslocado para bairros da orla marítima, seguindo tendência observada durante o século passado. 
Segundo Saboya (2017), estabelecimentos que comercializam bens de consumo frequente tendem a ter base territorial restrita, sendo normalmente acessados a pé, o que é interessante em termos de mobilidade urbana. Esses estabelecimentos possuem relação estreita com o estoque residencial do setor urbano em que se localizam. Portanto, se este se esvazia, como ocorreu com a área central, esses estabelecimentos são os primeiros a desaparecer, embora sejam eles que garantam a vitalidade urbana, pois são procurados constantemente, gerando maior movimentação nas calçadas durante o horário comercial. Assim, se o objetivo for recuperar a vitalidade na área, é imprescindível repovoá-la, pois, sem isso, atividades que comercializam bens de consumo constante não voltarão a aparecer.

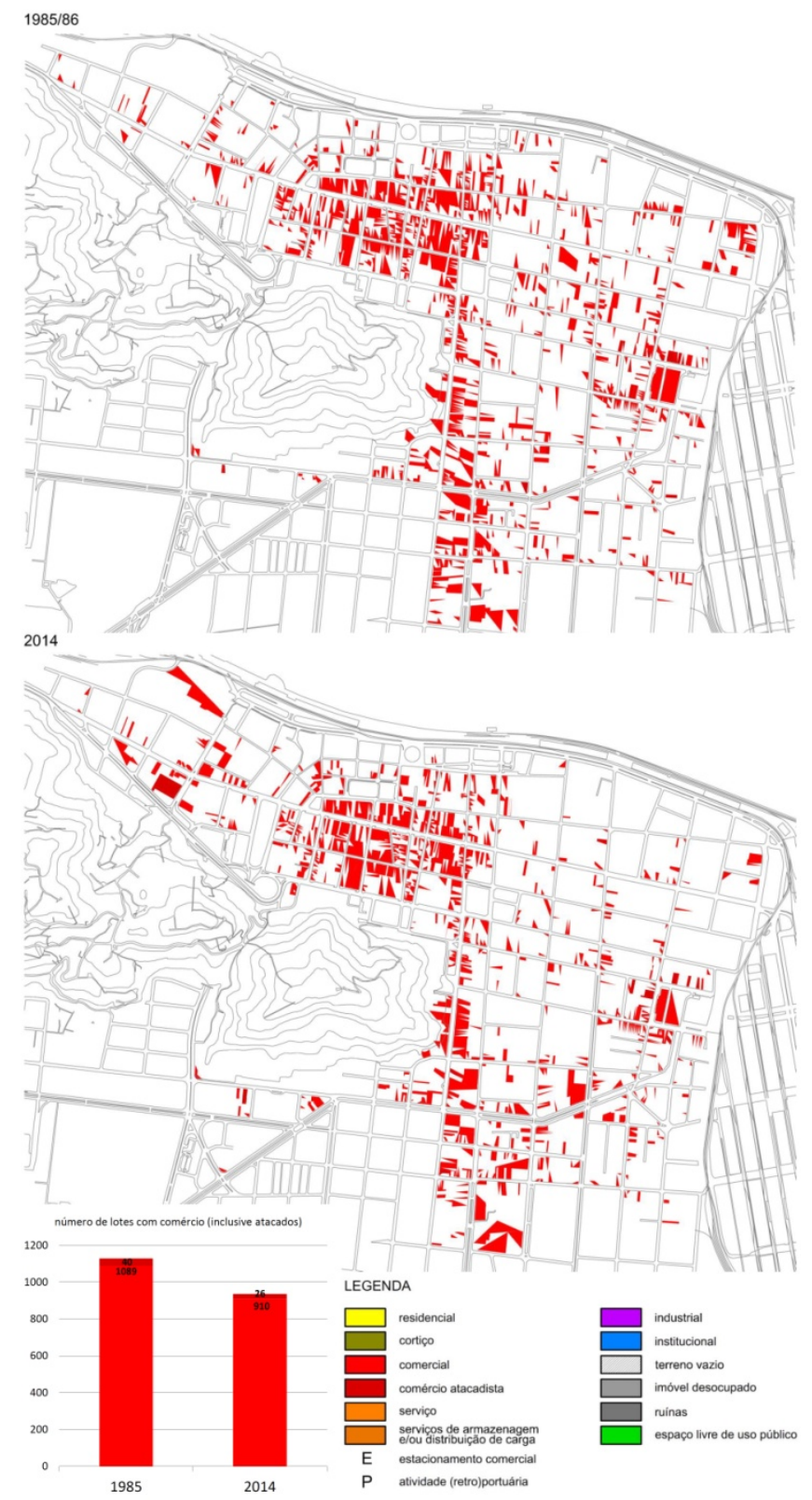

Figura 5 - Levantamentos de uso do solo comercial (1985/1986-2014). Fonte: Santos (2016).

Na Figura 6, apresenta-se a evolução das atividades prestadoras de serviços, incluindo armazenagem e distribuição de carga. Comparando-se os períodos, verifica-se que se manteve estável o número de lotes com prestação de serviços em geral, mas serviços de armazenagem ou transporte de cargas declinaram $13 \%$, enquanto os demais aumentaram aproximadamente $3 \%$. 
No Paquetá, não houve redução significativa de serviços vinculados ao porto, o que será explorado na discussão sobre zoneamento. Ao sul, na área do Mercado, essas atividades se espalharam, contribuindo para deterioração da paisagem e da ambiência urbana.

Essa dinâmica deve ser analisada de modo geral, pois a participação de alguns serviços na economia cresceu na última década no Brasil ${ }^{6}$. Portanto, a estabilidade dos serviços na área central pode indicar, inclusive, que eles não cresceram tanto quanto poderiam, caso o local não tivesse sofrido tamanha perda populacional.

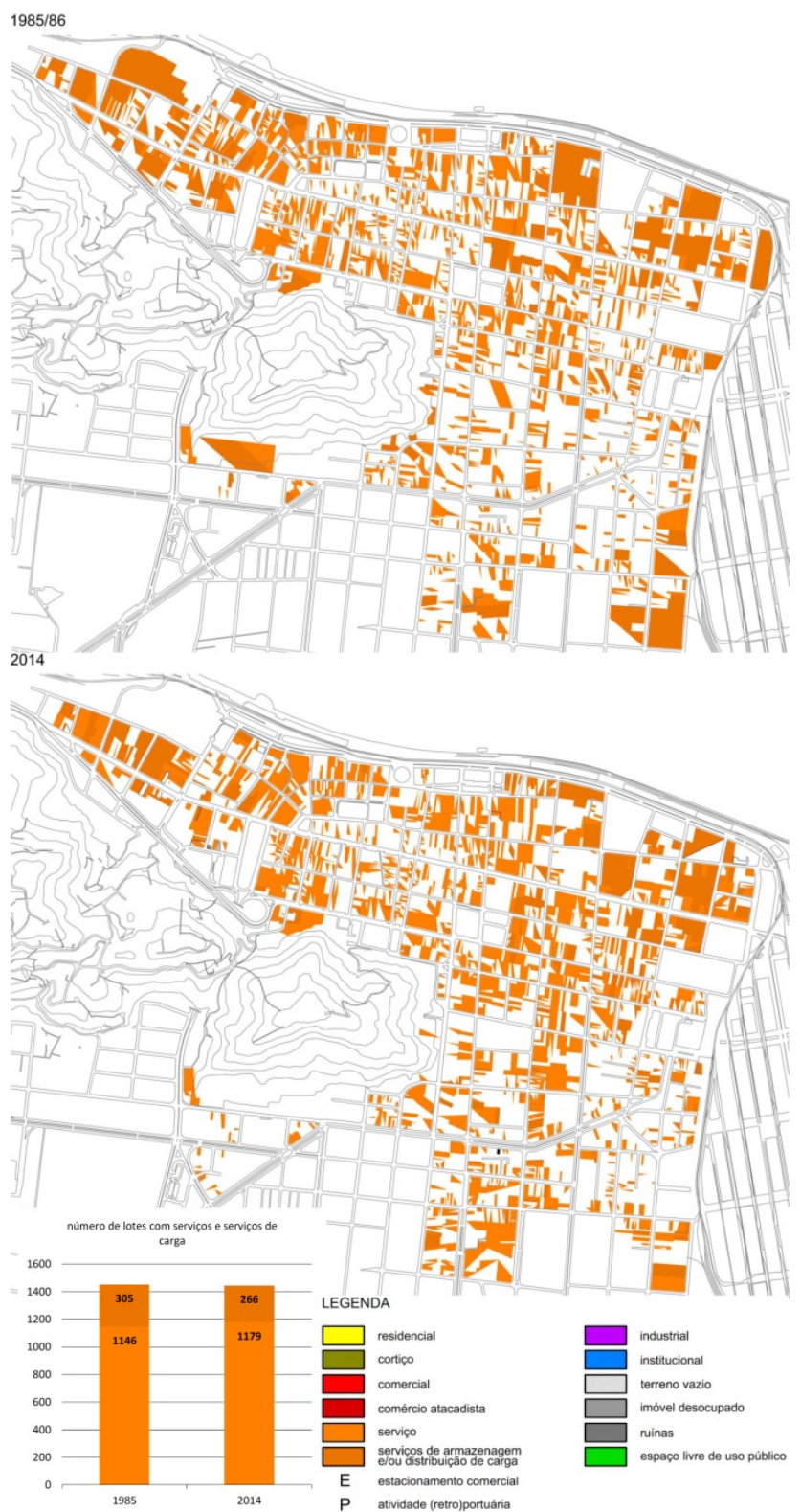

Figura 6 - Levantamentos de uso do solo de serviços (1985/1986-2014). Fonte: Santos (2016).

O estudo apontou também redução de $68,5 \%$ de estabelecimentos industriais, que passaram a se concentrar unicamente no Paquetá e praticamente desapareceram do Valongo, bairro que sofreu intensa transformação na última década por causa da instalação da unidade da Petrobras. Mesmo no

\footnotetext{
${ }^{6}$ Conforme a Pesquisa Anual de Serviços do IBGE (2015), entre 2007 e 2015 os setores de transportes e serviços auxiliares, importante em Santos, além dos serviços técnicos e profissionais, apresentaram crescimento expressivo em termos de receita operacional. Porém, é possível que as atividades de transportes e semelhantes tenham buscado outras localizações no período.
} 
Paquetá, as poucas atividades industriais eram estabelecimentos cristalizados, como Bunge e os moinhos Santista e Paulista, cuja lógica territorial depende da proximidade do porto.

Também é preciso analisar o declínio desse setor de forma ampla, pois a atividade industrial vem perdendo dinamismo em todo o mundo, pelo menos desde os anos 1970, em função das transformações produtivas apontadas em Negri \& Pacheco (1994) e Storper (2007).

Na Figura 7, apresenta-se a evolução da incidência de imóveis vazios, desocupados e em ruínas. Comparando-se os períodos, verifica-se redução em torno de $45 \%$ dos terrenos vazios e ampliação de aproximadamente $115 \%$ de imóveis desocupados. Observa-se aumento significativo dos imóveis desocupados em praticamente toda a área, o que também revela seu esvaziamento pelo terciário. Em 2014, eram poucos terrenos vazios sem uso, o que pode ser explicado pela ampliação do número de estacionamentos, como se verá adiante.

Naquele ano, havia 107 imóveis em ruínas, mas o levantamento de 1985/1986 foi considerado metodologicamente pouco confiável nesse quesito pela equipe responsável, sendo preferível desconsiderá-lo. Contudo, mesmo não sendo possível comparar os períodos, pode-se considerar que a quantidade de imóveis nessa situação é indicador importante do esvaziamento da área, assim como da ineficácia da política urbana incidente, em termos de capacidade de reconversão desse estoque.

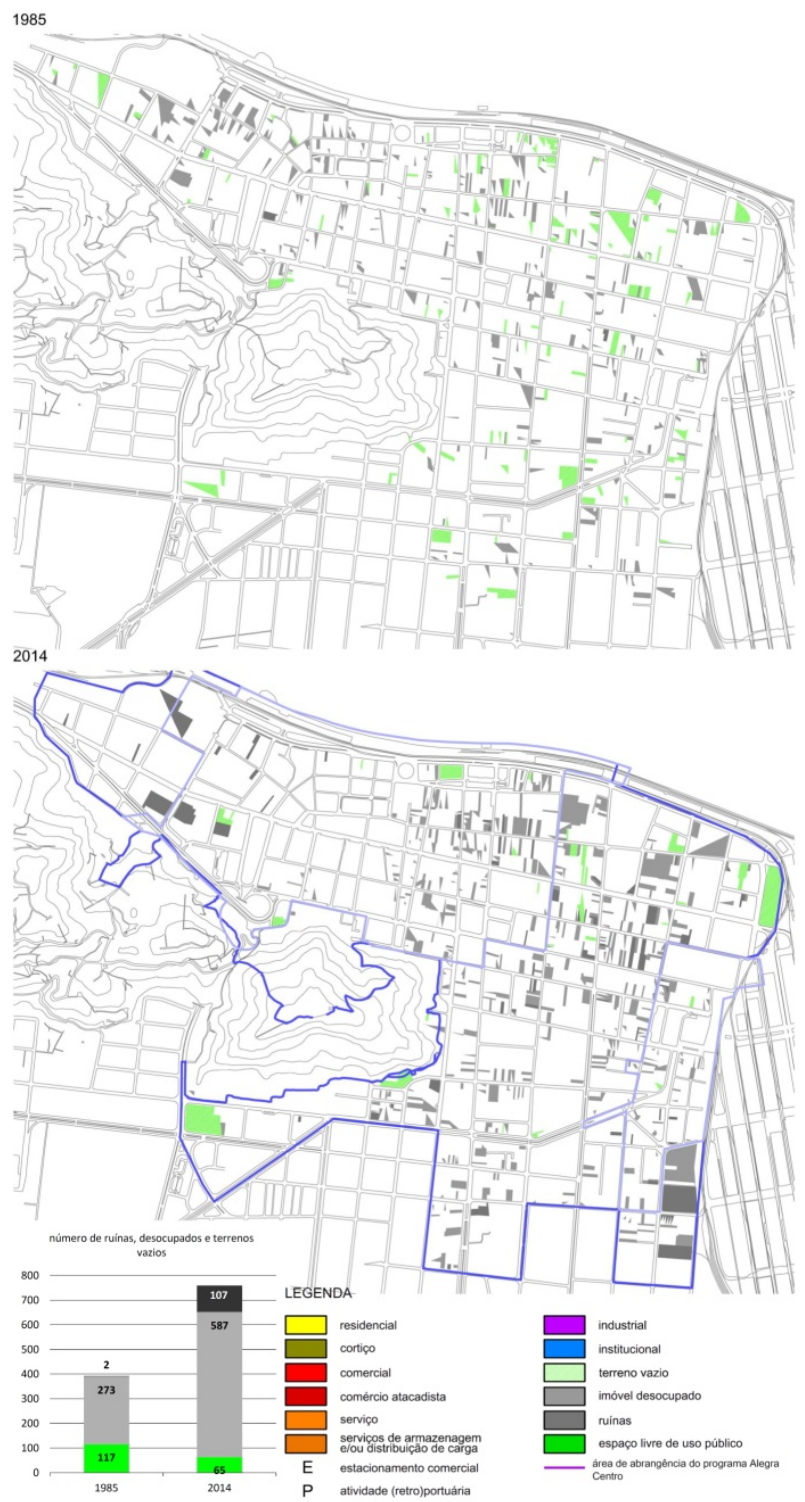

Figura 7 - Levantamentos de imóveis vazios, desocupados e em ruínas (1985/1986-2014). Fonte: Santos (2016). 
Observa-se generalizado descumprimento da função social da propriedade urbana, cujo enfrentamento se tornou viável a partir da sanção do Estatuto da Cidade (Brasil, 2001). Desde 2005, o município regulamentou a aplicação do parcelamento, edificação ou utilização compulsórios (PEUC), disciplinado no Estatuto (Santos, 2005), mas sua aplicabilidade tem sido muito reduzida. Além disso, antes do Plano Diretor (Santos, 2018) recém-aprovado, apenas Zonas Especiais de Interesse Social (ZEIS) estavam sujeitas ao PEUC, demonstrando a insuficiência da aplicação deste.

Na Figura 8, apresenta-se a localização dos lotes com estacionamentos nos dois períodos. No geral, houve acréscimo de 70\% dessa atividade. Em menor número, em 1985/1986, os estacionamentos se concentravam ao norte do Centro, e eram raros aqueles fora dessa localidade. Uma possível explicação para a disseminação dessa atividade foi a implantação do estacionamento regulamentado nos anos 1970.

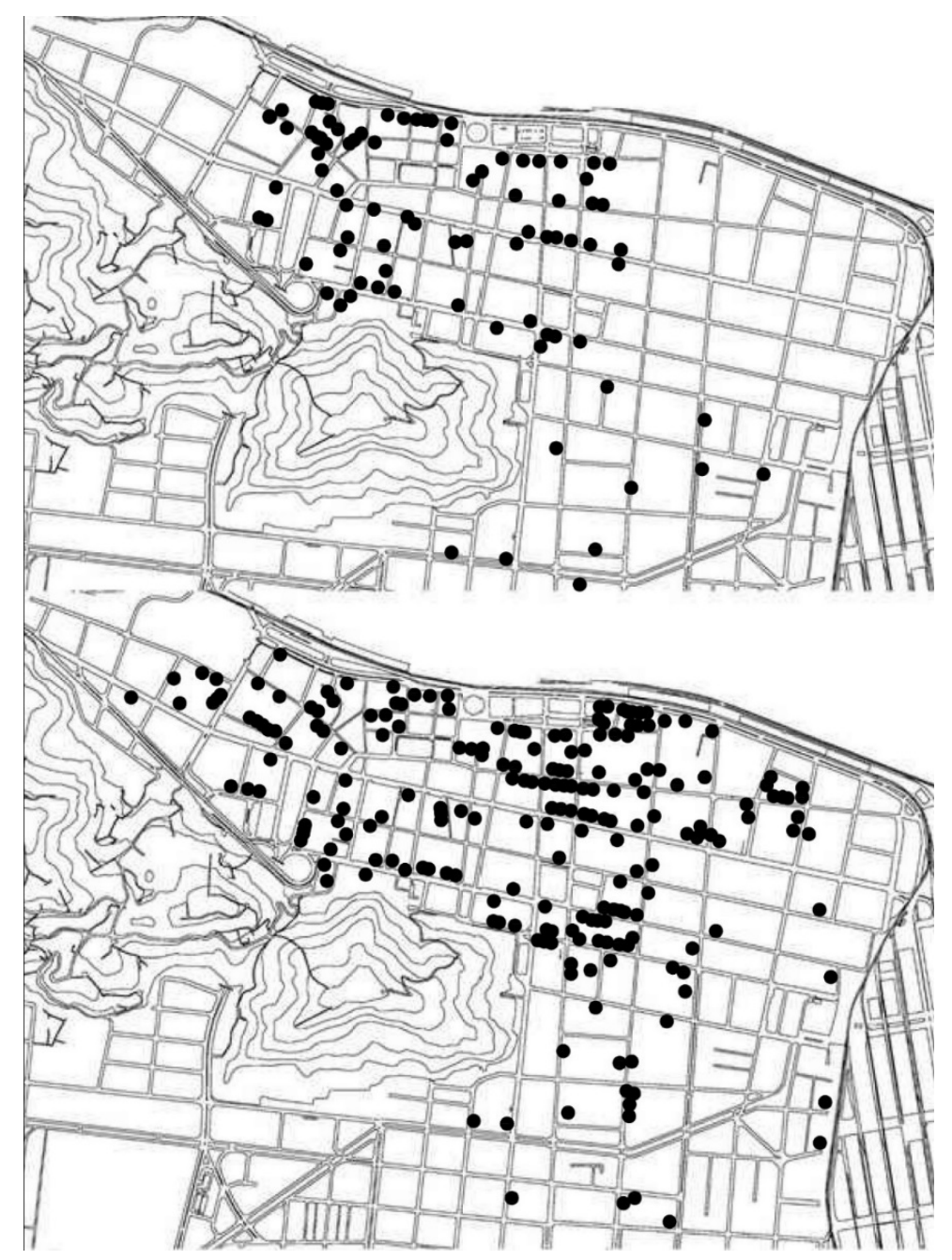

Figura 8 - Levantamento de imóveis usados como estacionamento (1985/1986-2014). Fonte: Santos (2016).

Pode-se verificar ainda o espalhamento dos estacionamentos para bairros pericentrais (Paquetá, Valongo e Vila Nova), sobretudo nos eixos viários, o que pode refletir a ampliação do uso de automóveis e motocicletas, conforme demonstram as Pesquisas Origem-Destino da Baixada Santista de 2007 (EMTU, 2008) e de 2012 (EMTU, 2013).

0 crescimento dos estacionamentos no Centro contribuiu para descaracterizar parte do conjunto arquitetônico, embora o programa Alegra Centro tenha proibido essa atividade em 2003 (Figura 9). 


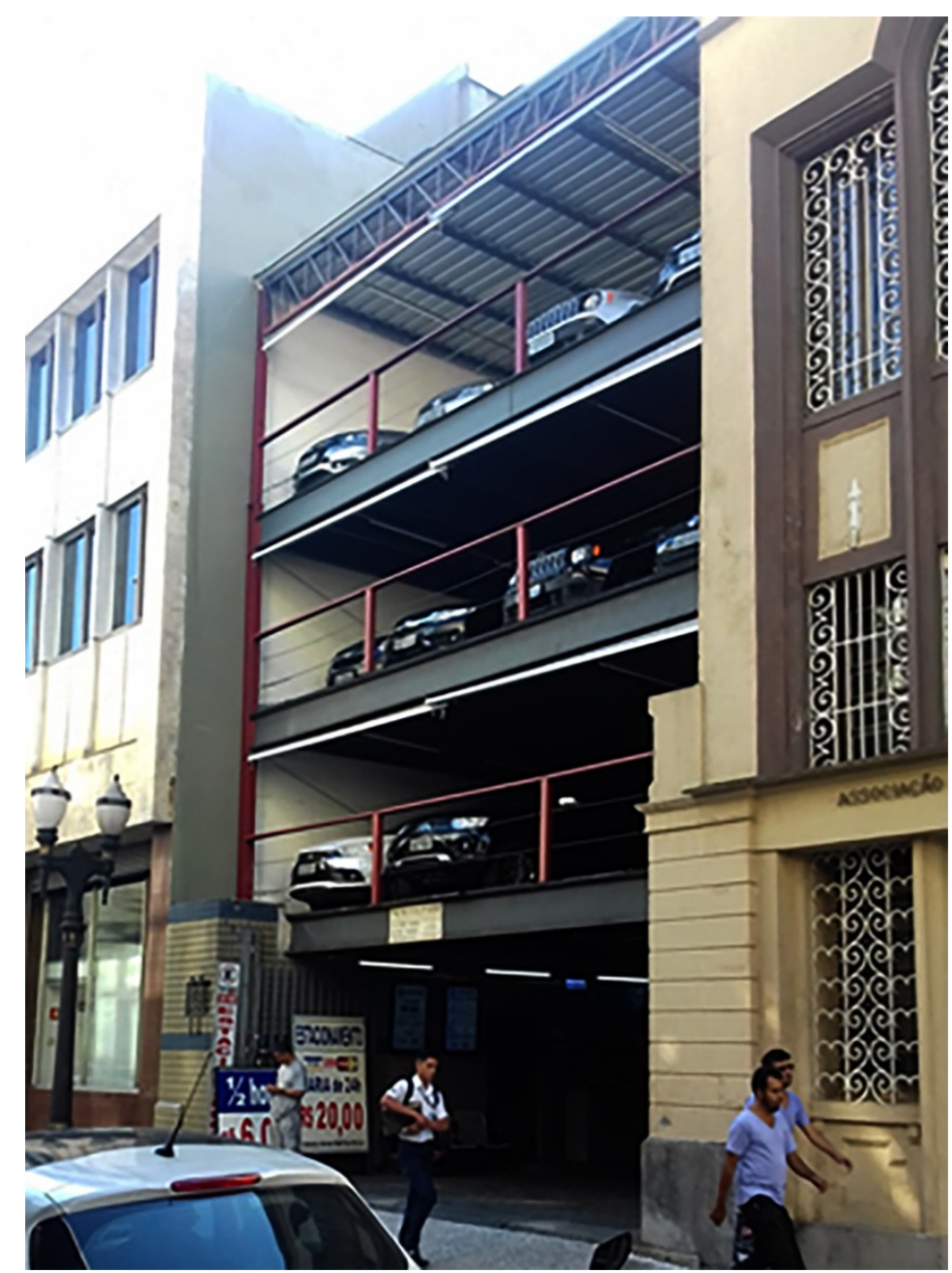

Figura 9 - Estacionamento irregular na Rua XV de Novembro. Fonte: fotografia dos autores (2018).

Quanto à evolução da ocupação dos lotes (Figura 10), utilizou-se comparativamente a base cartográfica cadastral do município, de 1945, e a base do SIGSantos, de 2014. Embora tenha havido ampliação de apenas $12 \%$ da ocupação dos lotes, o estudo revela elevado grau de modificação da estrutura da área, certamente vinculado à forte redução do uso residencial. A ampliação da ocupação do miolo das quadras certamente está vinculada ao abandono do uso dos fundos dos lotes como quintais das residências adaptadas para uso terciário.

A ocupação de 1945 foi bastante influenciada pelos zoneamentos de 1922 e 1945, que serão avaliados adiante. Além disso, a política de proteção desenvolvida após 1991 ocorreu de acordo com uma estrutura já existente em 1945.

Observam-se as maiores modificações no Paquetá, onde a ocupação dos lotes foi ampliada em razão das alterações do zoneamento, que privilegiaram usos industriais, portuários e retroportuários. Ao sul, na Vila Nova e em parte da Vila Mathias, também são observadas, por causa da concentração admitida pelos sucessivos zoneamentos, modificações relevantes de atividades, como serralherias, marcenarias e oficinas, que resultaram em grande ocupação dos lotes. 


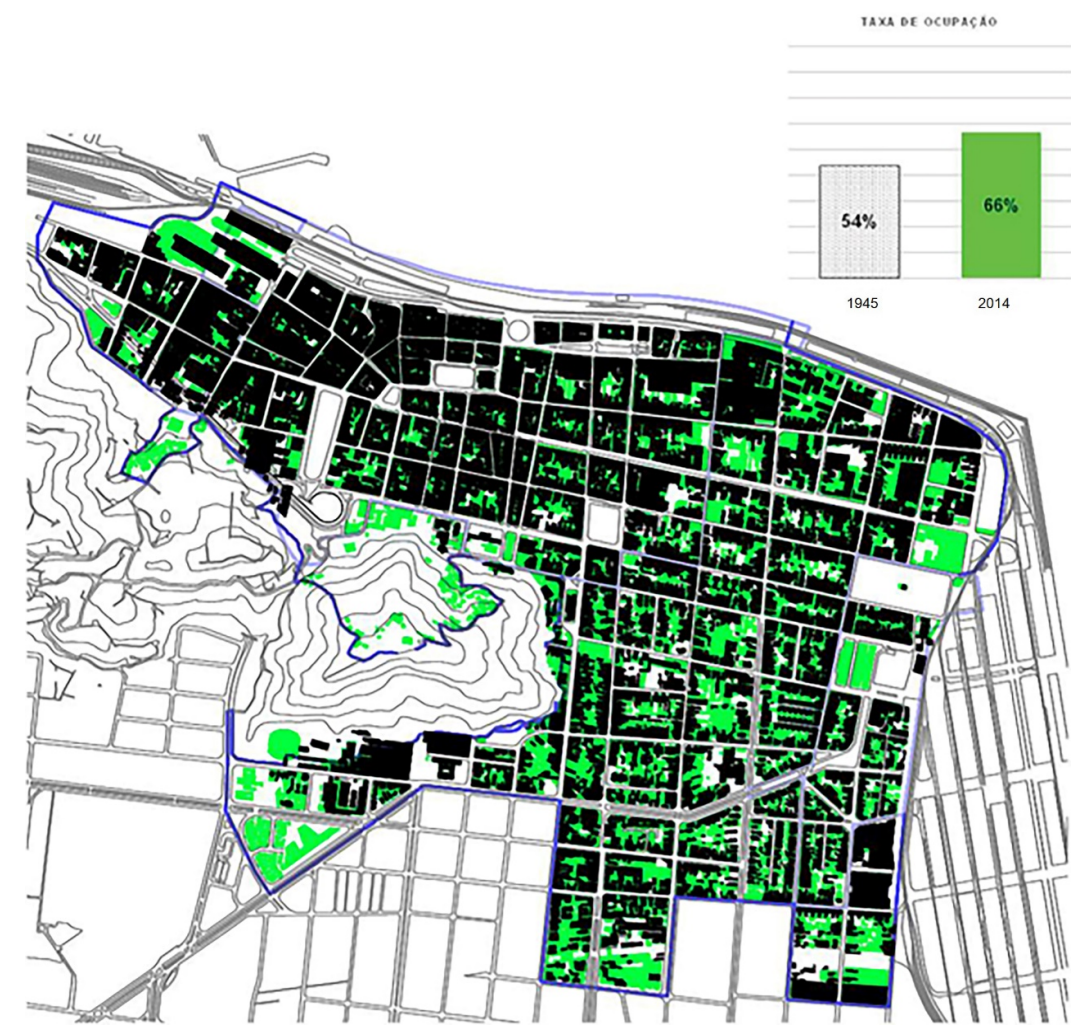

Figura 10 - Ocupação dos lotes. Fonte: Santos (2016).

No bairro Centro, sobretudo ao norte, onde havia grande concentração de terciário e usos institucionais, a ocupação dos lotes já era intensa em 1945. Mas, nessa área, a oferta de áreas livres públicas, mantida até hoje, era satisfatória. Esse aspecto não foi observado a leste e ao sul da área, onde há ausência quase total de praças, à despeito de diretriz nesse sentido instituída pelo Plano Regulador de Desenvolvimento e Expansão Urbana (Santos, 1951).

\section{A política de proteção do patrimônio histórico e o esvaziamento da área central}

Aspecto relevante aferido pelo estudo foi o papel da política de proteção do patrimônio histórico edificado, iniciada em 1991, no processo de esvaziamento da área central. Para esse fim, realizou-se o cruzamento entre dados referentes a terrenos vazios, imóveis desocupados e imóveis gravados com os níveis 1 e 2 de proteção cultural (NP-1 e NP-2), comparando os anos de 1985, 2002 e 2014, conforme a Figura 11.

Embora em 1985 não estivesse ainda vigente a política de proteção cultural implementada a partir de 1991 e aprofundada em 2003, decidiu-se por espacializá-la também para o período anterior, possibilitando verificar a importância da estratégia empreendida no atual quadro do estado geral de degradação da ambiência urbana e do patrimônio construído, protegido ou não, localizado na área de abrangência do programa Alegra Centro.

Dessa análise, excluíram-se imóveis gravados com níveis de proteção mais brandos, NP-3a, NP-3b e NP-4, pois pouco interferiam na liberdade de modificação do imóvel, principal reclamação de setores da sociedade local quanto à política de proteção cultural. Ruínas também não foram consideradas por causa das inconsistências mencionadas.

Observa-se que a criação de uma política de incentivo à proteção do patrimônio histórico, aprofundada em 2003, foi acertada ao se projetar o cenário de esvaziamento e possível substituição de edificações que teria ocorrido, caso a tendência observada entre os anos de 1985 e 2002 permanecesse, considerando a grande ampliação de imóveis vazios e desocupados verificada nesse período, particularmente na Área de Proteção Cultural 1 (APC 1), localizada majoritariamente no bairro Centro. 
Apesar do aumento significativo dos imóveis vazios e desocupados, o percentual deles na APC 1 , sobre o total de imóveis vazios e desocupados da área de abrangência como um todo, era em torno de $44 \%$, em 2002, contra aproximadamente $50 \%$, em 1985 . 0 contrário ocorreu para imóveis localizados na APC 2, que apresentaram aumento marginal em termos relativos de aproximadamente 1\%. Já para imóveis localizados fora das APC, observou-se aumento em torno de 5\% de imóveis vazios e desocupados, entre 1985 e 2002, sobre o total de imóveis vazios e desocupados para a área, em cada período.

A comparação com 2014 permite questionar os óbices à política de proteção cultural como estímulo à ocupação e à utilização dos imóveis, pois a evolução do padrão de desocupação parece corresponder mais a outras dinâmicas urbanas e socioeconômicas, pois os números são praticamente os mesmos, tanto para o intervalo dos períodos em que não havia incidência da política de proteção e de seu início quanto para o período posterior, entre 2002 e 2014, quando esta já vigorava.

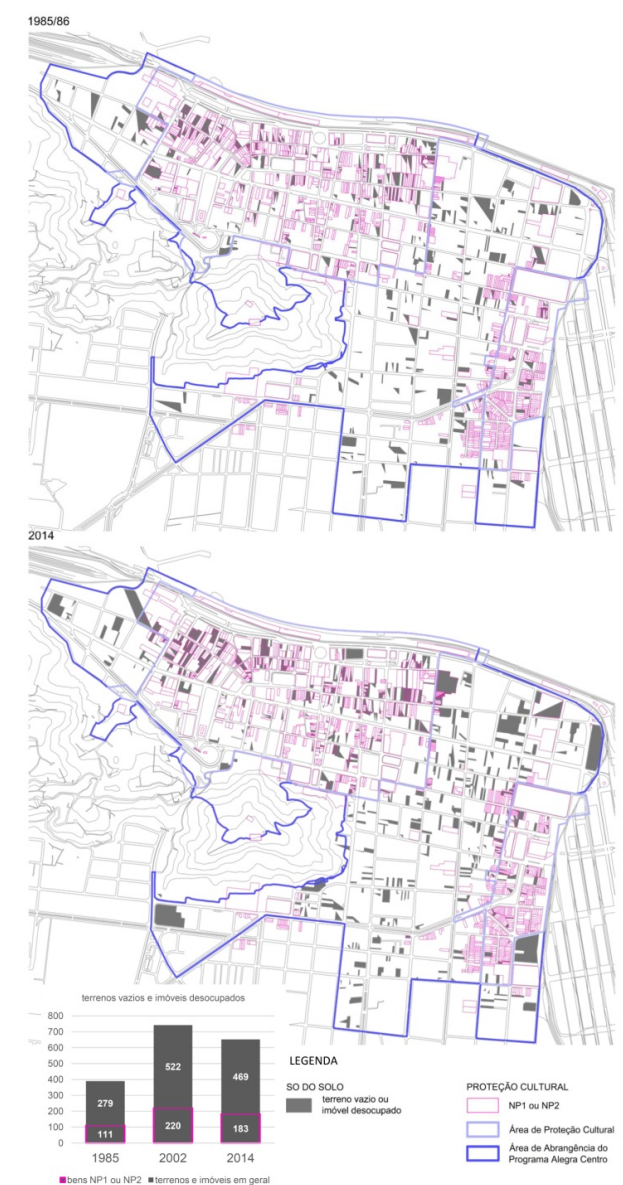

Figura 11 - Imóveis vazios e desocupados gravados como NP1 e NP2 (1985/1986-2014). Fonte: Santos (2016).

Embora, em termos absolutos, entre 1985 e 2002, tenha havido aumento significativo dos imóveis vazios e desocupados, gerando degradação da ambiência urbana e dos imóveis em si, em termos relativos, se comparados os três períodos, verificou-se tendência de manutenção do aumento ou da redução, independentemente do período analisado.

Na comparação dos dados relativos às APC 1 e APC 2, nas quais há concentração de imóveis normatizados, observou-se que, em ambas, houve pequeno decréscimo quanto aos imóveis vazios e desocupados entre 2002 e 2014. Considerando que os incentivos tributários concedidos pelo programa Alegra Centro, em sua maioria, ocorreram na APC $1^{7}$, acredita-se que foi a necessidade de áreas para os

\footnotetext{
${ }^{7}$ Conforme dados de 2013, da seção Escritório Técnico do Alegra Centro (SETAC/SEDURB).
} 
usos residenciais (cortiços) e de alguns serviços que manteve a APC 2 ocupada, promovendo, inclusive, a redução do percentual de desocupação, e não o programa em si.

A análise dos três períodos demonstra que, apesar de ter havido queda entre 2002 e 2014 do imóveis vazios e desocupados em termos absolutos, os percentuais dos imóveis com essas características entre os normatizados (NP-1 ou NP-2) se manteve o mesmo, em torno de $28 \%$, tanto para o período entre 1985 e 2002 quanto para o período entre 2002 e 2014.

Comparando o mapeamento de vazios e desocupados de 2002 e 2014, percebe-se uma redução nas áreas do Valongo e a leste, entre as áreas de proteção cultural, assim como um pequeno aumento na Vila Mathias.

Portanto, é possível que a política de proteção não tenha sido suficiente para reverter uma tendência provocada por outros fatores, como crise econômica e conflitos de uso do solo, que incidem há mais tempo do que os períodos estudados.

Em parte, pode-se inferir que deficiências da política de proteção cultural incidente na área central estão vinculadas ao descolamento entre esta e a política urbana que incide na cidade como um todo, posto que as "tendências" da dinâmica imobiliária estão mais relacionadas às transformações ou à falta delas na área central do que ao controle urbanístico. É importante a superação dessa visão fragmentada da cidade, sob pena de anulação do papel direcionador do desenvolvimento urbano da municipalidade, predominando apenas sua função reguladora de dinâmicas preexistentes na cidade.

\section{Evolução do zoneamento 1922-2014}

A Figura 12 apresenta a evolução do zoneamento de uso e ocupação do solo da área insular, desde sua adoção, em 1922, até 2011. Portanto, estudou-se um período marcado pelo diálogo e depois pelo divórcio entre correntes de planejamento e de urbanismo com bases culturalistas e progressistas (Choay, 2013).

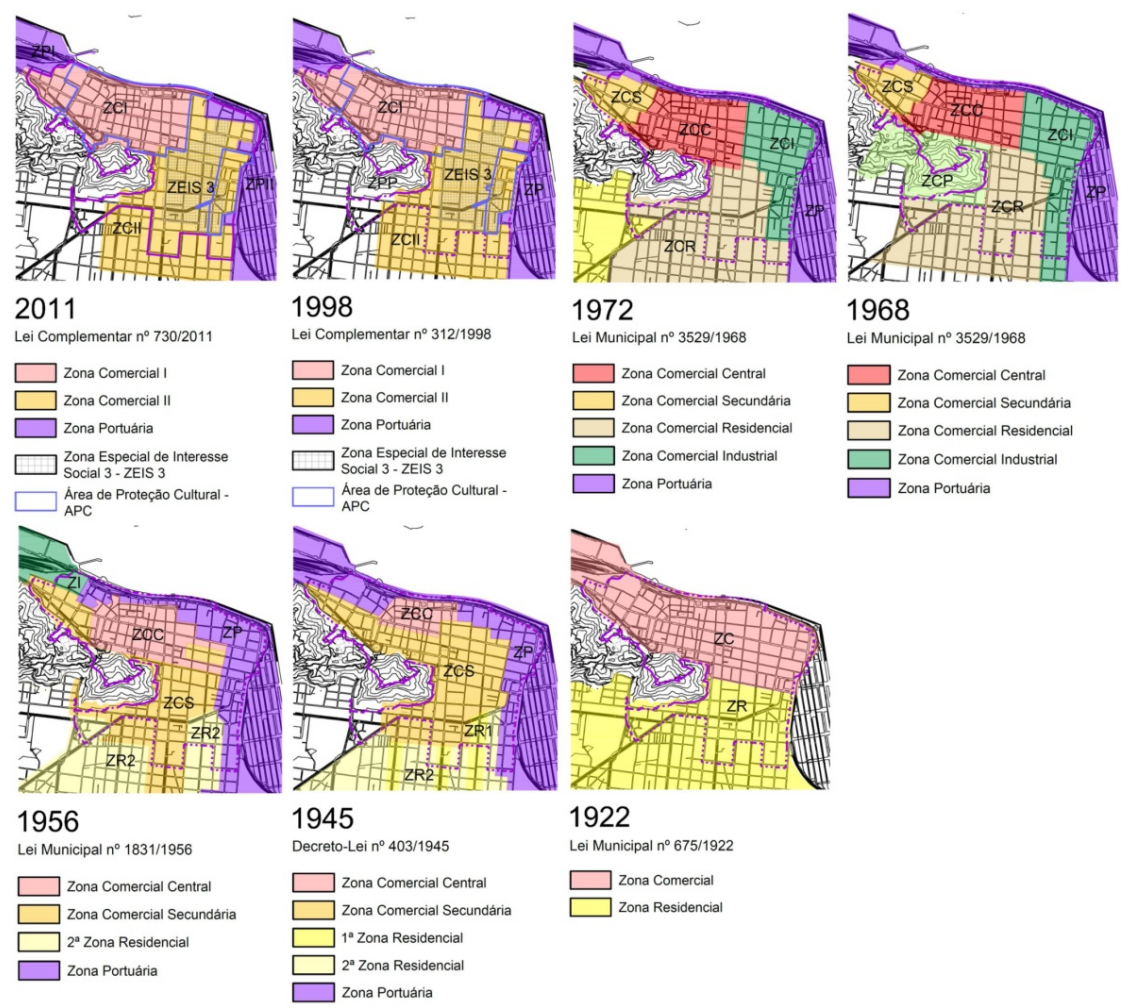

Figura 12 - Evolução do zoneamento de uso e ocupação do solo (1922-2011). Fonte: Santos (2016).

Até 1945, a preocupação com a paisagem urbana e com a oferta de bons espaços públicos era presente. Graças à política de preservação do patrimônio histórico, foi essa a paisagem que prevaleceu 
na área. No pós-guerra, com a disseminação do uso do automóvel e as alterações do zoneamento que procuraram ajustar a cidade a essa nova realidade, tornou-se importante garantir o domínio dessa forma de deslocamento, privilegiando-se também a "criação arquitetônica" privada, em detrimento da ambiência e da paisagem.

Nesse período, importantes alterações de uso do solo consolidaram-se graças ao zoneamento, como proibição do uso residencial no Centro e estímulo a atividades portuárias, retroportuárias e atacadistas do Plano Diretor de 1968 (Santos, 1968).

Foi esse zoneamento, vigente até 1998, que permitiu a instalação de atividades industriais em partes dos bairros Centro, Vila Nova e Paquetá, efetivando a transformação paulatina desse último, predominantemente residencial nos anos 1940, em área industrial e, depois, retroportuária e portuária. Assim, como consequência da evolução dos zoneamentos portuários (Figura 13), atividades com elevado nível de impactos ambientais aprofundaram o processo de esvaziamento residencial descrito.
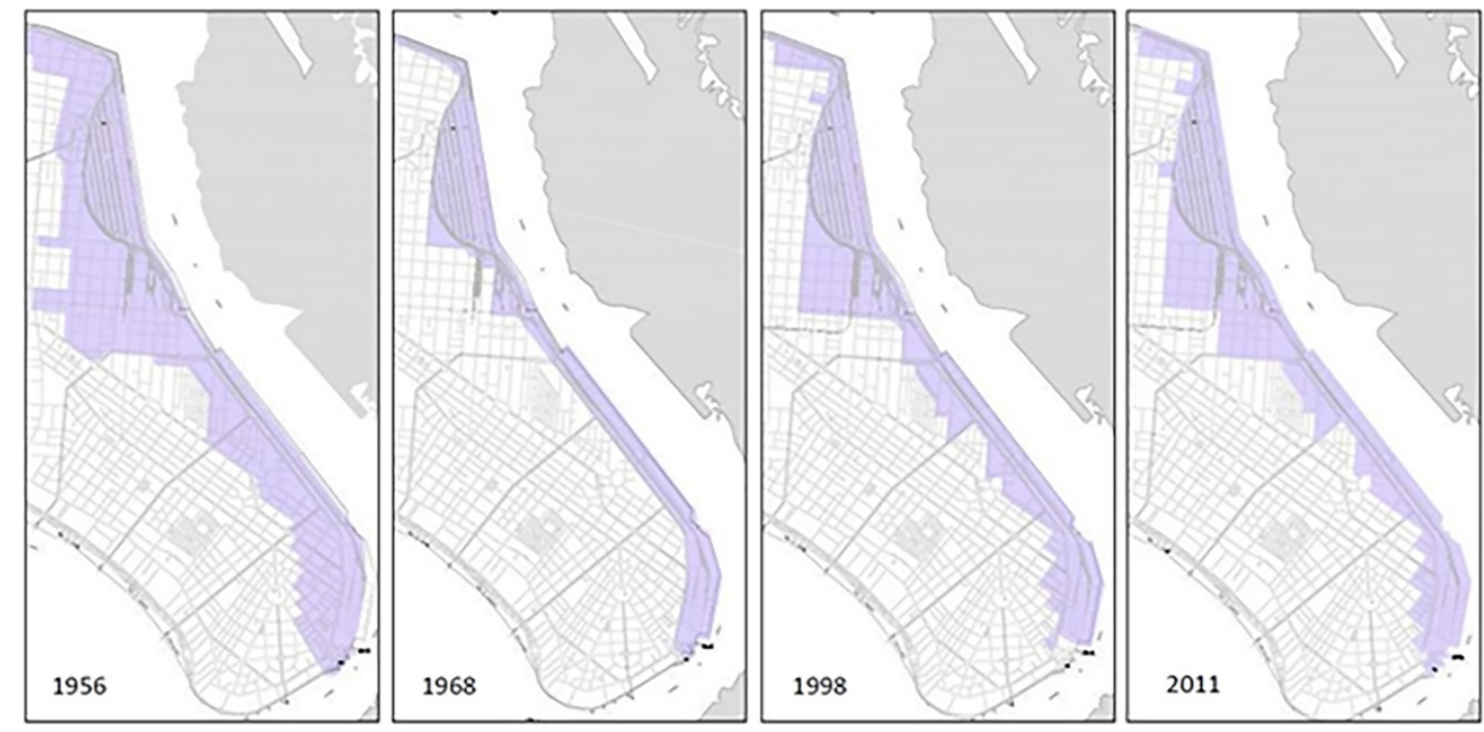

Figura 13 - Evolução da zona portuária. Fonte: Santos (2014).

Embora o bairro Vila Nova também tenha sofrido com essa alteração, tornou-se menos interessante a implantação dessas atividades, possivelmente por causa das maiores dificuldades de circulação de veículos de carga em razão do sistema viário desse subsetor.

Com a sanção da lei de ZEIS (Santos, 1992), partes dos bairros Paquetá e Vila Nova foram delimitadas como ZEIS 3, em que são prioritários a garantia do direito à moradia e o enfrentamento da questão dos cortiços. Porém, a produção de habitação de interesse social nessa área não é obrigatória, exceto no caso dos imóveis gravados pelo Decreto no 5.642, de 2010 (Santos, 2010a), que regulamentou o programa Alegra Centro - Habitação (Santos, 2010b). Contudo, esse programa não obteve sucesso, sobretudo pela ausência de mecanismos de financiamento para a reabilitação de cortiços, o que, em articulação com instrumentos coercitivos do programa, poderia resultar em efetiva transformação da área.

A evolução das zonas portuárias sobre a área leste da cidade denota a pressão que essa atividade imprimiu nos bairros residenciais, transformando a estrutura fundiária e toda a dinâmica da área, muitas vezes para abandoná-la posteriormente. Se, por um lado, a degradação da ambiência urbana, que esse movimento causa, afasta o uso residencial, por outro, embora perversamente, garante o acesso da população empobrecida à moradia próxima aos locais de emprego, precariamente por meio da ocupação do parque construído por um processo de encortiçamento. Esse movimento é parte integrante daqueles descritos por Abramo (2007), realizados pelo mercado imobiliário na promoção de novos produtos e localizações imobiliárias, com a criação do "mark up" urbano, incluindo campanhas de depreciação dos estoques antigos como estratégias para o deslocamento dos grupos sociais de interesse para novas localizações urbanas. 
Também se destaca a ineficácia da efetivação dos instrumentos de política urbana do Estatuto da Cidade, relatada anteriormente, que foi crucial para o fracasso das diretrizes contidas na lei de ZEIS e no programa Alegra Centro - Habitação, uma vez que não foi implementado o PEUC nem foram criadas condições para a aplicação da transferência do direito de construir, que poderia ter tornado a área central mais atrativa para a produção habitacional.

A Figura 14 possibilita analisar as permissões de uso atualmente vigentes (quanto mais clara a cor, maior o número de atividades impactantes permitidas), considerando-se tanto o impacto dos usos para o desenvolvimento das atividades residenciais quanto a necessidade da regulamentação destes na cidade, de forma integrada e inter-relacional, sob o ponto de vista da efetivação do processo de transformação urbana, que promova o adensamento da região central. Assim, revela-se um abismo entre as diretrizes instituídas no Plano Diretor, seu discurso e a prática institucionalizada na lei de uso e ocupação do solo.

Esse cartograma, além de representar uma clara distinção entre zonas da cidade passíveis de receber atividades incômodas para desenvolvimento do uso residencial e aquelas nas quais estas são permitidas, também denota a falta de coordenação completa do processo de ocupação do território pelo poder público municipal, posto que o zoneamento estabelecido é "cumulativo", ou seja, apenas acrescenta atividades conforme a categoria das vias, e não vocacionado, conforme define o Plano Diretor. Não há incentivo, termo muito utilizado no discurso, e sim uma grande liberdade de atuação do mercado conforme sua conveniência.

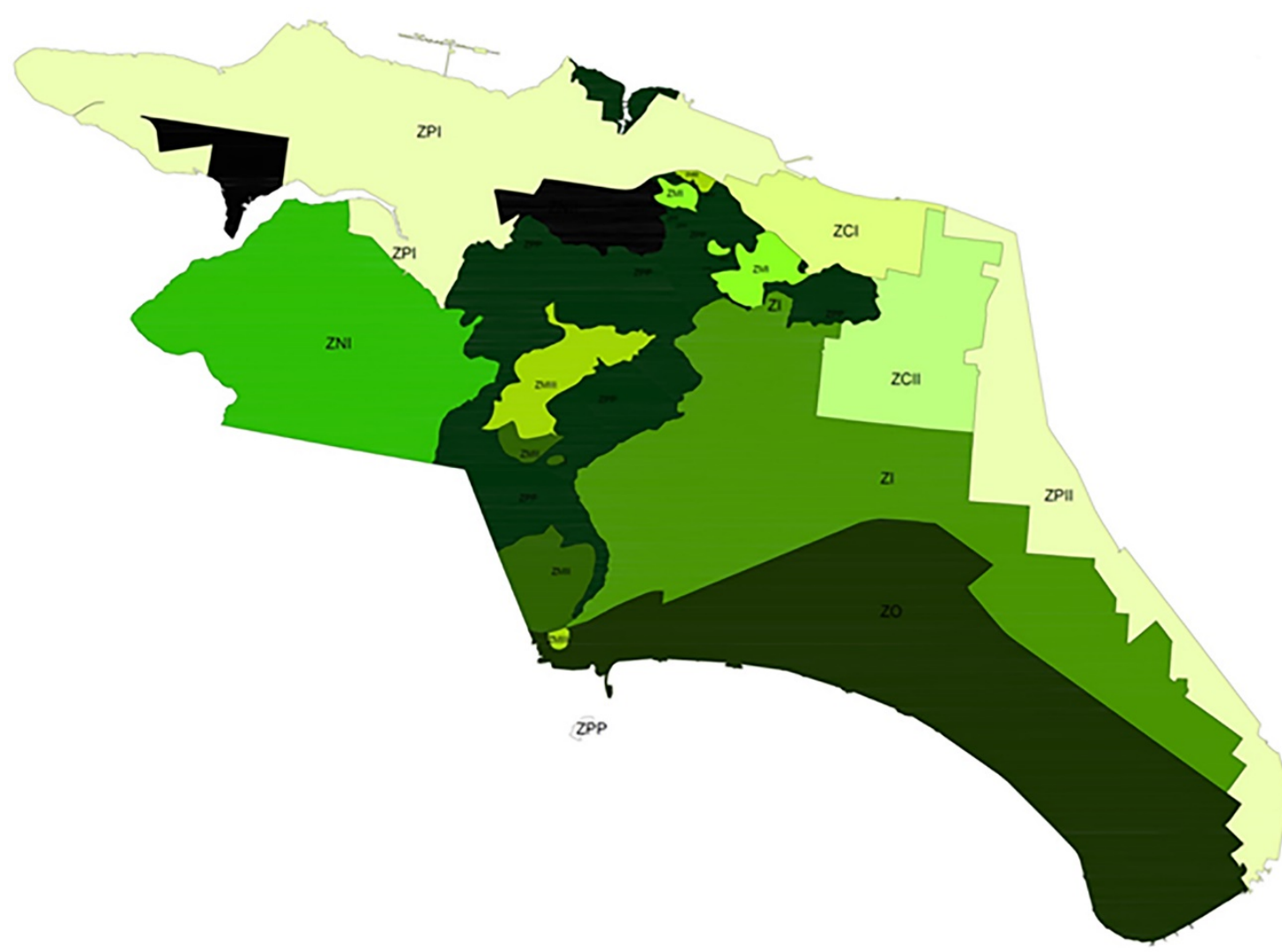

Figura 14 - Grau de restrição das permissões de uso por zona. Fonte: elaborada pelos autores (2018).

Nota-se que as duas áreas sobre as quais incide a política de proteção cultural foram aquelas que mais sofreram com as alterações do zoneamento portuário e permanecem ainda hoje prejudicadas pelo zoneamento vigente, contraditoriamente à diretriz de repovoamento definida no Plano Diretor. É penoso lembrar, nesse sentido, que foi justamente a incompatibilidade entre as atividades comerciais e de serviços no núcleo inicial de ocupação da cidade que gerou a insatisfação das classes mais abastadas e ensejou a criação do primeiro bairro aristocrático na região central no final do século XIX, o Paquetá, 
uma das primeiras áreas a serem completamente modificadas com a introdução das atividades portuárias e retroportuárias.

O repovoamento da área central, embora seja diretriz do atual Plano Diretor (Santos, 2018), só será alcançado caso os usos incompatíveis com as residências sejam paulatinamente deslocados das áreas com maior potencial de renovação, sobretudo nos bairros Paquetá, Vila Nova e Vila Mathias. Sem que isso ocorra, os demais usos vinculados ao consumo frequente das famílias permanecerão afastados da área.

\section{Conclusão}

A partir da análise da morfologia urbana da área central de Santos, sobretudo quanto à evolução do uso do solo, entre 1985 e 2014, assim como do processo de urbanização de Santos, durante o século XX, e do papel da regulação urbanística nesse processo, observou-se expressivo esvaziamento no que se refere ao uso habitacional, com reflexo em atividades econômicas vinculadas ao consumo das famílias.

Essa dinâmica foi motivada pelas transformações econômicas e produtivas que afetaram o papel do Centro de Santos. Ao mesmo tempo que o porto crescia, aumentavam-se, por causa de suas atividades de apoio, os impactos ambientais sobre a população residente, estimulando o deslocamento para outras áreas. As famílias com maior rendimento passaram a ocupar loteamentos próximos à orla marítima, enquanto as de baixa renda se deslocaram para assentamentos precários em áreas periféricas ou nos municípios vizinhos. Parte da população de baixa renda permaneceu na área central, residindo predominantemente em cortiços, por causa do papel que a localização possui quanto às despesas familiares com deslocamentos.

Assim, verificou-se o aumento de cortiços no período estudado, especialmente em parte dos bairros Vila Nova e Vila Mathias, além de aumento significativo de imóveis desocupados, principalmente no bairro Paquetá. Isso ocorreu apesar da regulamentação do PEUC no município desde 2005, que não garantiu o cumprimento da função social da propriedade urbana na área central. Contudo, houve generalizada redução de terrenos vazios.

Esse processo de degradação e esvaziamento evidenciado pela análise morfológica teve efetiva ligação com os zoneamentos em vigor desde 1922, sempre permissivos no tocante às atividades mais impactantes, sobretudo nos bairros Paquetá, Vila Nova e Valongo, promovendo mudanças morfológicas deletérias.

A partir dos anos 1990, desenvolveu-se uma política de preservação do patrimônio histórico edificado dessa área, aprofundada em 2003, contribuindo para manter algum dinamismo econômico, sem, contudo, articular-se à ineficaz política habitacional, adotada em 2010, a qual não continha instrumentos efetivos de financiamento para reabilitação de cortiços.

No entanto, disseminou-se na sociedade local o falso entendimento de que foi a política de proteção a promotora do esvaziamento da área central. Porém, este estudo não indica evidências de vínculo entre essa política e o esvaziamento e a degradação da área. Mas, se essa política for aperfeiçoada, poderá promover o repovoamento da área central, desde que garanta o cumprimento da função social da propriedade e o adequado direcionamento de investimentos públicos e privados, orientados por novo regramento urbanístico, que assegure respeito à sua paisagem natural e edificada, potencializando o patrimônio histórico, de acordo com as diretrizes do Plano Diretor em vigor.

Com a possível implantação da segunda fase do VLT, abre-se perspectiva para a adoção de política urbana com foco na equidade social, em parte da área suscetível à renovação urbana, assim como para o desenvolvimento de projetos de reabilitação de edifícios degradados, privilegiando o repovoamento dessa área.

Portanto, é estratégica a articulação entre políticas de proteção e de habitação direcionadas para faixas de menor renda, que são a maior parte da demanda. Deve-se incentivar também comércio e serviços no nível da rua, com usos extensivos ao residencial, ativos durante a maioria do tempo, apoiados em desenho urbano inclusivo, que garanta a ampliação dos espaços de uso público em toda a 
área, maior conectividade do tecido urbano e estímulo a modos ativos de deslocamento, complementando o transporte público.

Por fim, deve-se considerar a falta de coordenação do processo de planejamento pela municipalidade, que, ao promover o uso homogêneo, generalizado e gratuito de altos índices de aproveitamento do solo na cidade, além de impedir a utilização de instrumentos com grande potencial de geração de receitas, tanto para a preservação do patrimônio, por exemplo, a Transferência do Direito de Construir, quanto para um fundo de financiamento de intervenções de requalificação urbana com a Outorga Onerosa do Direito de Construir, reforça movimentos de deslocamento do mercado imobiliário, os quais não guardam relação alguma com o interesse público ou com a demanda por habitação.

Assim, acredita-se que este trabalho contribua para a discussão honesta quanto à apuração de responsabilidades dos diversos agentes sociais de produção e gestão do espaço urbano, a fim de construir alternativas que promovam o uso e a apropriação democráticos do espaço urbano. Considerase ainda que as reflexões aqui apresentadas poderão ter validade para casos correlatos de esvaziamento de centros urbanos, ressalvadas as especificidades regulatórias e referentes ao porte da cidade e ao porto de Santos.

\section{Referências}

Abramo, P. (2007). A Cidade Caleidoscópica. Coordenação Espacial e Convenção Urbana: uma perspectiva heterodoxa para a convenção urbana. Rio de Janeiro: Bertrand Brasil.

Andrade, W. T. F. (1989). O Discurso do Progresso: a evolução urbana de Santos. 1870-1930 (Tese de doutorado). Faculdade de Filosofia, Letras e Ciências Humanas, Universidade de São Paulo, São Paulo.

Andrade, W. T. F. (1995). Santos: urbanismo na época do café. 1889-1930. In Pereira, M. A. F. (Org.). Café - Santos \& História. Santos: Leopoldianum. Recuperado em 04 de junho de 2018, de http://www.novomilenio.inf.br/santos/h0214.htm

Brasil. (2001, 11 de julho). Lei Federal n. 10.257, de 10 de julho de 2001. Que estabelece diretrizes gerais da política urbana. Brasília: Diário Oficial da União.

Carriço, J. M., \& Barros, M. F. (2015). Crise de mobilidade urbana em Santos/SP: produção imobiliária, segregação socioespacial e desenraizamento. In: Anais do XVI Encontro Nacional da Associação Nacional de Pós-Graduação e Pesquisa em Planejamento Urbano e Regional (pp. 1-20). Belo Horizonte: ANPUR.

Carriço, J. M., \& Souza, C. D. C. (2016). Sustentabilidade urbana e padrão de ocupação do solo: os paradigmas da evolução da mancha urbana na Região Metropolitana da Baixada Santista. In A. E. Salvi, \& C. B. Perez (Orgs.). Ambiente e Sustentabilidade. (1a ed., p. 53-68). Santos: Leopoldianum.

Choay, F. (2013). O Urbanismo. Utopias e Realidades. Uma Antologia (7a ed.). São Paulo: Perspectiva.

Del Rio, V. (1990). Introdução ao desenho urbano no processo de planejamento. São Paulo: Pini.

Empresa Metropolitana de Transportes Urbanos - EMTU. (2008). Sumário de dados da Pesquisa Origem-destino 2007, Região Metropolitana da Baixada Santista. São Paulo: Secretaria de Estado dos Transportes Metropolitanos, EMTU e VETEC Engenharia.

Empresa Metropolitana de Transportes Urbanos - EMTU. (2013). Pesquisa Mini Origem-Destino Domiciliar da RMBS, 2012 - Apresentação. São Paulo: Secretaria de Estado dos Transportes Metropolitanos, EMTU.

Instituto Brasileiro de Geografia e Estatística - IBGE. (2010). Censo Demográfico de 2010 - Resultados. Rio de Janeiro: IBGE. Recuperado em 16 de maio de 2018, de https://censo2010.ibge.gov.br/resultados.html.

Instituto Brasileiro de Geografia e Estatística - IBGE. (2015). Pesquisa Anual de Serviços. Rio de Janeiro: IBGE. Recuperado em 15 de maio de 2018, de https://www.ibge.gov.br/estatisticas-

novoportal/economicas/servicos/9028-pesquisa-anual-de-servicos.html?=\&t=series-historicas. 
Instituto Pólis (2013). Relatório regional do diagnóstico urbano socioambiental do Litoral Paulista. São Paulo: Instituto Pólis.

Lang, J. (1987). Creating Architectural Theory: The Role of the Behavioral Sciences in Evironmental Design. Nova Iorque: Van Nostrand Reihold.

Leme, M. C. S. (Org.) (1999). A formação do pensamento urbanístico no Brasil: 1895-1965. Urbanismo no Brasil: 1895-1965. São Paulo: Studio Nobel.

Negri, B., \& Pacheco, C. A. (1994). Mudança tecnológica e desenvolvimento regional nos anos 90: a nova dimensão espacial da indústria paulista. Revista Espaço e Debates, 38, 62-82.

Saboya, R. (2017). Usos do solo: uma introdução à localização dos usos comerciais. Recuperado em 19 de junho de 2017, de http://urbanidades.arq.br/2017/02/usos-do-solo-uma-introducao-a-localizacao-dos-usos-comerciais/.

Santos. Prefeitura Municipal (1951). Lei no 1316, de 27 de dezembro de 1951. Plano Regulador de Desenvolvimento e Expansão Urbana. Santos: Diário Oficial Urgente.

Santos. Prefeitura Municipal. (1968, 16 de abril). Lei $n^{\circ}$ 3.529, de 16 de abril de 1968. Plano Diretor Físico do Município de Santos. Santos: Prodesan.

Santos. Prefeitura Municipal. (1992, 16 de maio). Lei Complementar no 53, de 15 de maio de 1992. Cria as Zonas Especiais de Interesse Social (ZEIS). Santos: Diário Oficial Urgente.

Santos. Prefeitura Municipal. (2003, 05 de fevereiro). Lei Complementar $n^{\circ}$ 470, de 06 de fevereiro de 2003. Cria o Programa de Revitalização e Desenvolvimento da Região Central Histórica de Santos. Santos: Diário Oficial de Santos. p. 8-13.

Santos. Prefeitura Municipal. (2010a, 30 de julho). Decreto no 5.642, de 29 de julho de 2010. Regulamentou a Lei Complementar $n^{\circ}$ 688, de 29 de julho de 2010, que cria o programa de reabilitação de uso residencial na região histórica de Santos - "Alegra Centro - Habitação". Santos: Diário Oficial de Santos. p. 9-11.

Santos. Prefeitura Municipal. (2010b, 30 de julho). Lei Complementar no 688, de 29 de julho de 2010. Cria o programa de reabilitação de uso residencial na região histórica de Santos - "Alegra Centro - Habitação". Santos: Diário Oficial de Santos. p. 6-8.

Santos. Prefeitura Municipal. (2014). Diagnóstico da Secretaria de Desenvolvimento Urbano - SEDURB para revisão da delimitação das Zonas Portuárias de Santos - processo de revisão da lei de uso e ocupação do solo da área insular do Município de Santos. Mimeografado.

Santos. Prefeitura Municipal. (2016) Diagnóstico da Secretaria de Desenvolvimento Urbano - SEDURB para Revisão dos Programas Alegra Centro e Alegra Centro Habitação- Relatório de Trabalho. Mimeografado.

Santos. Prefeitura Municipal. (2018, 17 de julho). Lei Complementar no 1.005, de 16 de julho de 2018. Santos: Diário Oficial de Santos.

Storper, M. (2007). Who benefits from industrial decentralization?: social power in the labor market, income distribution and spatial policy in Brazil. Regional Studies, 18(2), 143-164. http://dx.doi.org/10.1080/09595238400185141.

Whitehand, J. W. (2013). Morfologia urbana Britânica: a tradição Conzeniana. Revista de Morfologia Urbana, 1(1), 45-52.

Editor: Fábio Duarte

Recebido: Jun. 05, 2018

Aceite: Dec. 09, 2018 